\title{
The future of corporate governance: Network governance - a lesson from the financial crisis
}

\author{
Michael Pirson ${ }^{\mathrm{a}, \mathrm{b}, *}$ and Shann Turnbull ${ }^{\mathrm{c}}$ \\ ${ }^{a}$ Schools of Business, Director, Center for Humanistic Management, Fordham University, NY, USA \\ ${ }^{\mathrm{b}}$ Research Fellow, Harvard University, New York, USA \\ ${ }^{\mathrm{c}}$ International Institute for Self-governance, Sustainable Money Working Group (UK), Sydney, Australia
}

\begin{abstract}
US alone in the first two years after Lehman Brothers collapse. In its wake $45 \%$ of world's wealth has been destroyed and three of the largest bankruptcies in the US have occurred. Just as the majority of observers thought lessons from Enron had been learned, crisis had struck again. Massive government intervention, the collapse of the banking system, and public outrage at the missteps of executives have highlighted once more the weaknesses of mainstream corporate governance systems. Contrary to popular opinion the principal cause of the crisis was not sub-prime mortgage defaults but a failure of corporate governance, states the Association of Chartered Certified Accountants. While the OECD is brainstorming new corporate governance codes, public policy makers are calling for more comprehensive and tougher regulation. How likely will those changes help to prevent a future crisis? Not very likely, we argue, unless we fundamentally rethink the underlying failures inherent to the Anglo- Saxon structure of corporate governance and regulation. In the following article, we thus examine the systemic shortcomings of Anglo-Saxon corporate governance that arise from too much power being vested in a single board. We also lay out alternative governance models based on the natural science of communication and control. We then identify why a single board cannot adequately and reliably control the complex firms that wield influence over our lives. Examples of alternative models provide evidence that managers can design governance architectures that significantly reduce the risk of systematic blind spots, and the ensuing massive wealth destruction.
\end{abstract}

Keywords: Corporate governance, financial crisis, network governance, corporate architecture, corporate boards, humanistic governance

10.2 trillion dollars have been lost in the US alone in two years after the collapse of Lehman Brothers [1]. $45 \%$ of world's wealth has been destroyed as a consequence [2] and three of the largest bankruptcies in the US have occurred in the following year. ${ }^{1}$ Just as the majority of observers thought lessons from Enron had been learned, crisis had struck again. Massive government intervention, the collapse of the banking system, and public outrage at the missteps of executives have

\footnotetext{
${ }^{1}$ http://www.bankruptcydata.com/Research/Largest_Overall All-Time.pdf, (accessed on June 2, 2009).

*Corresponding author: Shann Turnbull, Ph.D., Principal: International Institute for Self-governance, Co-founding Member: Sustainable Money Working Group (UK), PO Box 266 Woollahra, Sydney, 1350, Australia. Cell: +61418 222 378; Tel./Fax: +612 8065 5905; E-mail: sturnbull@mba1963.hbs.edu.
}

again highlighted the weaknesses of mainstream corporate governance systems. Contrary to popular opinion the principal cause of the crisis was not sub-prime mortgage defaults but a failure of corporate governance, states the Association of Chartered Certified Accountants [3]. While the OECD has recommended new corporate governance codes, ${ }^{2}$ public policy makers are calling for more comprehensive and tougher regulation. How likely will those changes help to prevent a future crisis? Not very likely, we argue, unless we fundamentally rethink the underlying failures inherent to the Anglo- Saxon structure of corporate governance and regulation.

\footnotetext{
${ }^{2}$ http://www.oecd.org/document/48/0,3343,en_2649_34813_42 192368_1_1_1_1,00.html, (accessed on June 2, 2009).
}

0167-2533/15/\$35.00 @ 2015 - IOS Press and the authors. All rights reserved

This article is published online with Open Access and distributed under the terms of the Creative Commons Attribution Non-Commercial License. 
Table 1

Follows the analysis by Downs (1967:116-118)

\begin{tabular}{|c|c|c|c|c|c|}
\hline Hierarchy & & rmation upwa & & & \\
\hline Public or private sector & Volume & Correct & Missing & & vith a \\
\hline Legislature & $(50 \%$ & ( $85 \%$ of & or wrong & spa & trol of \\
\hline Minister/shareholders & lost/level) & lower level) & meaning & say & s/level \\
\hline Board of directors & $3.1 \%$ & $1.4 \%$ & $98.6 \%$ & Level & Accum \\
\hline Chief executive officer & $6.3 \%$ & $3.3 \%$ & $96.7 \%$ & 1 & 1 \\
\hline Senior management & $12.5 \%$ & $7.7 \%$ & $92.3 \%$ & 5 & 6 \\
\hline Middle management & $25.0 \%$ & $18.1 \%$ & $81.9 \%$ & 25 & 31 \\
\hline Team leaders & $50.0 \%$ & $42.5 \%$ & $57.5 \%$ & 125 & 156 \\
\hline Workers & $100.0 \%$ & $100.0 \%$ & $0.0 \%$ & 625 & 781 \\
\hline
\end{tabular}

In the following article, we thus examine the systemic shortcomings of Anglo-Saxon corporate governance that arise from too much power being vested in a single board. We also lay out alternative governance models based on the natural science of communication and control [4]. We then identify why a single board cannot adequately and reliably control the complex firms that wield influence over our lives. Examples of alternative models provide evidence that managers can design governance architectures that significantly reduce the risk of systematic blind spots, and the ensuing massive wealth destruction.

1) Communication failures in corporate hierarchies are systematic when controlled by a single board

The blame for Lehmann Brother's downfall and the entire financial crisis seems to have been placed on subprime mortgage defaults. However, bad loans and high risk have always been around and are part of business. The real issue is not the existence of high risk loans, but rather the inability of organizations and management to detect such risks and take appropriate action. While there is a debate about the role unethical behavior or incompetence played in causing the crisis, ${ }^{3}$ we agree with the assessment of the Association for Chartered Certified Accountants, that the failure of the Anglo Saxon governance system was the principal cause of the crisis.

"In early 2007, few senior managers thought they were betting on the viability of their banks. It appears they did not understand the risks and were using risk assessment with tools which were inappropriate. Boards may not have expended the necessary time and energy, and/or lacked the expertise to ask the right questions."[2]

\footnotetext{
${ }^{3} \mathrm{http}: / /$ axisoflogic.com/artman/publish/Article_55707.shtml, (accessed on May 29, 2009).
}

Governance failures lead to insufficient risk detection, as well as what psychologists call "mindless blindness" [5]. But how can boards and management have systematically turned a blind eye to the fundamental financial risk of their organizations? It turns out that the American dependence on a unitary board induces systemic communication failures.

Let's take a step back. We all remember the fun party game of Telephone. What made it fun was that the meaning of the original message got consistently distorted as it was relayed through a chain of individuals. What is entertaining at parties can be dangerous in an environment in which important decisions are made based on that information. In business contexts, we know that, in addition to being relayed through a chain of individuals, information can be abbreviated, and conflicts of interest may systematically bias the information sent.

To illustrate this point further, let us do a thought experiment. Let us assume that managers in a hierarchy only report $50 \%$ of the information available to their superiors. In practice one could expect that it would be much less. Further assume that, because of misinterpretation and/or the conflicts of interest, $15 \%$ of the information relayed is inaccurate, biased or misleading. When a message has to pass through five levels to go from sender to ultimate receiver, the message has lost more than $96 \%$ of its original content, as illustrated in Table 1. Though this is quite astounding, it reflects the situation that exists in many traditional command and control based organizations.

As a consequence of these systemic distortions, it is unsurprising that CEO's and their directors are often not being fully informed of existing business risks. Especially so when it is never in the interest of any subordinate to report problems for which he/she could be held accountable. 
Table 2

Mondragón compound board compared with Unitary Board

\begin{tabular}{|c|c|c|c|c|c|c|}
\hline \multirow{3}{*}{$\begin{array}{l}\text { Board type } \\
\text { Control } \\
\text { Centers }^{\mathrm{a}}\end{array}$} & \multicolumn{5}{|c|}{ Mondragón compound board } & \multirow{2}{*}{$\begin{array}{c}\text { Anglo } \\
\text { Unitary }\end{array}$} \\
\hline & Watchdog & Supervisory & Management & Social & Work & \\
\hline & Council & Board & Board & Council & Unit & Board \\
\hline & 3 & $5-8$ & $4-6$ & $\sim 5-25$ & $\sim 10-20$ & $\sim 4-12$ \\
\hline Functions ${ }^{\mathrm{b}}$ & $\begin{array}{c}\text { Governance } \\
\text { processes }\end{array}$ & $\begin{array}{c}\text { Appoint Mgt } \\
\text { Board }\end{array}$ & $\begin{array}{c}\text { Organise } \\
\text { operations }\end{array}$ & $\begin{array}{l}\text { Worker } \\
\text { welfare }\end{array}$ & $\begin{array}{l}\text { Production } \\
\text { Elect S.C. }\end{array}$ & Manage \\
\hline $\begin{array}{l}\text { Activities } \\
\text { Activities }\end{array}$ & $\begin{array}{c}\text { Efficacy \& } \\
\text { integrity of } \\
\text { processes }\end{array}$ & $\begin{array}{c}\text { Integrate } \\
\text { strategic } \\
\text { stakeholders }\end{array}$ & $\begin{array}{c}\text { Efficient } \\
\text { allocation of } \\
\text { resources }\end{array}$ & $\begin{array}{l}\text { Establish } \\
\text { working } \\
\text { conditions }\end{array}$ & $\begin{array}{l}\text { Job organ- } \\
\text { isation \& } \\
\text { evaluation }\end{array}$ & $\begin{array}{c}\text { Direct \& } \\
\text { control }\end{array}$ \\
\hline Internal $^{\mathrm{b}}$ & $X$ & & $X$ & $\mathrm{X}$ & $\mathrm{X}$ & $\mathrm{XXXX}$ \\
\hline External $^{\mathrm{b}}$ & $\mathrm{X}$ & $X$ & & & & XX \\
\hline Short term ${ }^{\mathrm{b}}$ & $\mathrm{X}$ & & $X$ & & $\mathrm{X}$ & $\mathrm{XXX}$ \\
\hline Long term ${ }^{\mathrm{b}}$ & & $\mathrm{X}$ & & $\mathrm{X}$ & & $\mathrm{XX}$ \\
\hline
\end{tabular}

Degrees of decomposition of information processing labour indicated by allocation of " $\mathrm{X}$ ". "Omits the General Assembly, which elects Watchdog Council and Supervisory board. ${ }^{b}$ Descriptions follow typology of Tricker (1994: 244 \& 287) with the typical number of people involved in each board.

Some scholars have argued argue that for superior governance boards only need to get the relevant information [15]. As a consequence, existing information asymmetries need to be reduced by building trust between the different hierarchical levels. By nature, however, hierarchies are ill equipped to foster trusting relationships because of power differentials. While we deem the establishment of trusting relationships very commendable, we are not convinced that existing systemic barriers can be overcome [15]. In 1949, Claude Shannon, a Bell Telephone communication scientist, mathematically proved that the accuracy of communications can only be improved by having additional communication channels to cross check accuracy; not by simply improving the ONE existing channel.

In the social context, law courts have unknowingly applied this natural law by requiring corroboration of independent witnesses. Journalists from responsible media organizations are likewise required to cross check their stories from independent sources. But directors and senior executives from the most responsible firms typically do not establish competing channels to cross- check information provided by management. More often than not they trust the accuracy of managerial information. Given the problem identified in the Table above, one can conclude that senior managers and their directors are irresponsible and/or naive in not obtaining the other side of the stories reported by management.
2) The actual level of control at the board level is insufficient

A second systemic failure of Anglo-Saxon boards is displayed by the limited ability of a few directors to control a large number of subordinates. In his Law of Requisite Variety Ashby argues that for adequate systemic control there needs to be a balance between controllers and the controlled [6]. Imagine a football game with 20 players in one team and 3 on the other. The team with 3 players will most likely lose as the control level is imbalanced, and all the fun of an exciting matchup would be lost.

Ashby observes that the ability to control cannot be amplified directly, but that instead it can be amplified indirectly by supplementation through one or more coregulators [7]. Picture a motel manager who needs to maintain a constant temperature in hundreds of rooms as the weather changes during the day. There are just so many rooms a single person can run around and adjust windows and blinds in. However, by installing air conditioners as co-regulators, one person can control many rooms by adjusting the thermostats. Similarly, a board member needs to make sure that the risks incurred by the different managers are at an acceptable level. The board and the CEO need to enhance their own control ability with 'organizational thermostats'. We argue that using internal and external stakeholders as co-regulators can help to establish the requisite variety that Ashby identified as necessary for stable systems. 


\section{3) Insufficient decomposition of decision making labor}

A third systemic weakness of current governance structures is that Directors and CEO's are subjected to information overload which leads to poor decision making. Despite the fact that only a small percentage of information actually makes it to the board level, board members are still overwhelmed. ${ }^{4}$ Information overload problems for management were mitigated when US firms changed from Unitary (U-Form) to Multidivisional (M-Form) firms early in the 20th century [8]. NO such adjustment was made for the corporate boards. European firms in contrast, had instituted decomposition of decision-making labor at the board level, with Supervisory Boards making strategic decisions and Management Boards making operative decisions. The mere establishment of separate functional board committees (audit committees and compensation committees) does not reduce the information processing of individual directors, it just compartmentalizes it. A much greater decomposition of decision making labor is possible when the number of decision makers is increased [9]. That is why companies in knowledge intensive, dynamic industries such as hi-tech, electronic, and bio-tech firms adopt a network structure, with experts for different aspects of their business operations [10].

4) Systematic power concentration increases likelihood of unethical behavior

A fourth systemic risk for unitary boards in AngloSaxon firms is that directors obtain absolute power to manage their own conflicts of interest and possess "at least six inappropriate powers giving rise to serious conflicts of interest" [11]. While in a law court the judge, the jury and the experts are all independent of the accused, in public companies directors (accused) have the power to appoint their own judges (auditors), determine their pay, select and remunerate so called "independent" advisors that will support their case to the jury (investors). This inherent structural flaw invites unethical behavior and suboptimal decisions for those that should be protected by the system: the auditors, shareholders and the public.

\section{Network governance as an alternative}

Many academics, practitioners and policy makers currently are debating how to reform corporate gov-

\footnotetext{
${ }^{4}$ http://www.thinkingmanagers.com/the-thinking-ceo/corpo rate-governance (accessed in April 12, 2009).
}

ernance. Suggestions range from establishing new metrics [12] to increasing board responsibility, ${ }^{5}$ and strengthening board competency [13]. Most of these suggestions assume that the unitary board structure is the optimal way to structure governance. We, however, argue that only a radical shift in governance structures can alleviate the blind spots currently enshrined in the unitary board structure.

Nature provides some fascinating examples of networked governance. When we study how the human brain works, we see that it governs supremely well based on the distribution of intelligence throughout numerous control centers. There is no hierarchical control center, rather several flexible organically changing areas that provide and simultaneously cross-check information. "The brain is like a committee of experts. All the parts of the brain work together, but each part

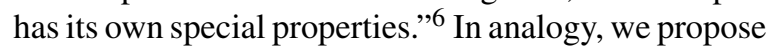
a corporate "network governance" system [14].

One of the most prominent examples of network governance is found in the structure of VISA International Inc before it went public. Founder Dee Hock describes Visa as a chaordic organization, based on four governing principles:

- Equitable ownership by all participants

- Distribution of power and function to the maximum degree

- Distribution of authority within each governing entity

- Malleability and durability of structures ${ }^{7}$

VISA is owned by 20,000 member institutions (mostly banks), and services all of them. VISA is governed by hundreds of boards, each having absolute discretion over a geographical area (group, regional, national and international). These boards independently appoint, review and discharge corporate executives, facilitate beneficial competition, approve cooperative projects and set fees within their area. ${ }^{8}$

Evidence of the efficacy of network governance can also be seen in the cooperative networks of Mondragón in Spain. Mondragón's 60,000 workers are also the owners of the more than 150 firms which constitute

\footnotetext{
${ }^{5}$ http://www.eyeofdubai.com/v1/news/newsdetail-26545.html (accessed April 7, 2009).

${ }^{6}$ http://www.sciencemaster.com/jump/life/brain.php (accessed April 13, 2009).

${ }^{7}$ www.fieldbook.com/DoC/breuner/ch5.html (accessed February 26, 2009).

${ }^{8}$ Ibid.
} 
Mondragón. Each of these 150 cooperatives has 5 separate boards: a supervisory board, a management board, a social council, a workers council and many work units. The twelve super-ordinate organizing groups are similarly governed with several independent boards to fulfill different functional tasks. Studies have reported that these firms have achieved unparalleled performance and resiliency in both good and bad times over many years [15].

As we will demonstrate, network governance (a) improves the accuracy of information because it introduces cross-checking channels of communication, (b) improves oversight, monitoring and control of risks by an increase in the number of controllers, (c) decomposes decision making labor to overcome information and computational overload; (d) creates a division of power with checks and balances to remove, manage and/or mediate conflicts and unethical behavior.

Many elements of network governance could be introduced without changes in the law, even with firms publicly listed. The benefits of network governance structures have long been noticed in highly competitive and dynamic industries. Over the past 30 years, an increasing number of unlisted firms have structured their governance on a network basis [16]. The research evidence supporting network governance is compelling, as is its logic, which is considered below. ${ }^{9}$

1) Network governance minimizes communication risks

Board members consistently complain about the reliability of information provided by management [13]. They express strong interest in obtaining information from a broader range of sources. ${ }^{10}$ When IT specialists respond to demands for high reliability internet connections, they make sure that there are many parallel channels that can be used to transport data. In case one channel fails, others can still provide the relevant information. In a similar way, corporate boards need to set up parallel communication channels. That way, board members can cross check all information they receive from management.

Who can serve as these parallel communication channels? All stakeholders involved with the organization possess potentially relevant information for one or more boards and can serve as these parallel communication channels. Several companies, including HP and Shell,

\footnotetext{
${ }^{9}$ We need to show more research here!

${ }^{10}$ https://www.mckinseyquarterly.com/Governance/Boards/The state_of_the_corporate_board_2007_A_McKinsey_Global_Survey_ 2011 ?pagenum $=3$.
}

are already using stakeholder councils in advisory functions. Other organizations already use stakeholder councils to gain strategic insights into their operations. ESA, the electric safety agency in Canada, for example, uses stakeholder councils to provide direct business insight to the board of directors. ${ }^{11}$ Many cooperatives structure their governance processes so that employees and customers are systematically heard by the board. Supervisory boards in German firms are required to include fifty percent of employee directors. VISA has structured its governance process around the owners and clients of its services. Boards of these firms are able to capture higher quality information because any information presented by management can be crosschecked with different stakeholders [18].

Overall, firms that are able to structure their governance systems so that they include the voices of key stakeholders (i.e. owners, employees, clients etc.) are able to increase the accuracy of information provided to their boards.

\section{2) Network governance increases control through} stakeholder engagement

Several management consultancies and public policy makers (e.g. OECD) suggest that competence of each board member is key to higher levels of responsibility. However, even they concede that it will be very difficult to recruit expert board members for all different aspects of each business operation. As Ashby stated, while it is impossible to directly amplify control exerted by a single board, there are ways to increase control by introducing co-regulators. So far that approach seems unrecognized as fundamental strategy for either directors or regulators. Customers, distributors, agents, suppliers, employees, unions and public interest activists routinely obtain business information. That information is not systematically shared with senior management or directors but could help them increase their ability to monitor and mitigate risk. While each category of stakeholder has different vested interests, many in direct conflict with those of other stakeholders; all share a common interest in preserving, if not enhancing the operations of the firm on which they depend. That reduces the likelihood of systematic biases.

Even if management had the highest integrity, it may not be fully informed of its exposure to problems and risks. Just one rogue trader can destroy a company, as demonstrated by the failure of Barings Bank in 1995 [19] or Societe General in 2008. Some

\footnotetext{
${ }^{11} \mathrm{http} / / / \mathrm{www}$. esainspection.net/Corporate/abt_006.php?s=0 (accessed on Nov 3, 2009).
} 
of the security traders in other banks were aware of the risk exposure being accepted. Unfortunately, like the individuals that had early concerns about Enron and many other corporate collapses, there was no systemic way to share these concerns with the board. Had there been such established channels, crucial information could have been retrieved much earlier. At John Lewis Partnership, a leading UK retailer, for example, employees have processes to voice their concerns with the board of directors directly. They also vote for representatives on the board, which ensures high levels of employee engagement and helps to protect the company from rogue employee behavior. In a similar way, customers at cooperative Raiffeisen bank in Switzerland, are represented on the board of directors and have direct access [20]. When management incurs risks that are not well understood, customers voice these concerns directly with the controlling board members. Therefore many cooperative banks stayed away from dealing with high-risk subprime mortgages. As a consequence many cooperative banks have been a winner of the financial crisis, attracting many new clients. ${ }^{12}$

To avoid future crises, it is necessary to install early warning systems. These systems need to use the intelligence of crucial stakeholders. Think about what could have been done to avoid the subprime mortgage crisis had all concerned employees and customers been heard before. Many consumers now willingly tell the press about the absurdities witnessed in the lending process, ${ }^{13}$ insiders such as Michael Lewis had pointed out the risks much earlier. If firms had introduced systematic stakeholder feedback independent from management, boards could have drawn important conclusions much earlier. A further upside of stakeholder engagement is that their respective self-interests provide sufficient incentive to offer intelligence without much cost.

Even though many examples we cite are drawn from the cooperative world, many of the insights can be applied in public companies as well. It is by amending corporate constitutions and by-Laws that shareholders can empower operational stakeholders so that they can be engaged independently of management to monitor management and to share responsibility as co-regulators on how the business is governed.

\footnotetext{
${ }^{12} \mathrm{http} / / / \mathrm{www} . \mathrm{drs} . c h / \mathrm{www} / \mathrm{de} / \mathrm{drs} /$ nachrichten/von-der-finanzzur-wirtschaftskrise/81633.91506.chronik-einer-beispiellosenkrise.html.

${ }^{13} \mathrm{http}: / /$ abcnews.go.com/thelaw/story?id=6021608\&page $=1$, (accessed on May 27.2009).
}

\section{3) Network governance Institutionalizes a division of labor at the board level}

Some corporate governance experts argue that "Boards are overwhelmed, overscheduled, undereducated and often uncoordinated in addressing key concerns of the enterprise and its stakeholders."14 Others say that boards are asked to perform unrealistic duties given their traditional structure, processes, and membership [21]. We agree that boards need to be redesigned to deal with the current information and task overload. Currently, unitary boards are asked to 1) provide long term strategic advice, 2) shape corporate policy while 3 ) monitoring and evaluating short term business and executive performance, and 4) being accountable to regulators and shareholders.

U.S. and U.K. corporations with unitary boards typically decompose decision making into only three committees, such as those concerned with auditing, remuneration or nomination. Using subcommittees does not remove conflicts, group loyalty or alleviate the information overload, as the same individuals are involved in the overall governing board as well.

At Mondragón, each of these four tasks is carried out by a separate control center, each constituted in a different manner [22].

- Long-term strategic direction is provided by the supervisory board which is composed of 5-8 members. The supervisory board's function is to appoint the management board and actively involve strategically relevant external stakeholders in the supervisory process.

- Employee remuneration, working conditions and welfare are determined by the social council that also has a long term focus but is inward oriented.

- Monitoring tasks are taken over by work units of 10-20 members. They appoint delegates to the Social Council.

- Accountability to internal and external audiences is ensured by the watchdog council. Three members ensure the efficacy and integrity of governance processes of the overall firm.

- The management board therefore is only dealing with operational organization and decides about the efficient allocation of resources. That way decision making in the governance process is decomposed in order to facilitate effective cooperation.

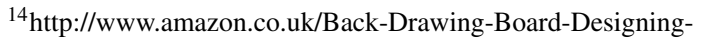
Corporate/dp/1578517761.
} 
The example of VISA International demonstrates that governance tasks can also be divided among geographical areas. All of the boards at VISA International had similar functional tasks, but each of them had a specific regional focus (similar structures can be found at the Raiffeisen banks in Europe or the Red Cross internationally). Whether board tasks are split up according to function or geography, both ways reduce the risk of task and information overload.

4) Network governance can introduce checks and balances on conflicts of interest

"Power tends to corrupt, and absolute power corrupts absolutely...". ${ }^{15}$ Lord Acton's premonitions have become an adage for students of governance. It is no wonder that a lot of effort in corporate governance has focused on conflicts of interest. The problem of unitary boards is that they have absolute power to manage their own conflicts of interests. Specifically when appointing outside auditors they create conflicts of interest for both directors and auditors. The purpose of an auditor is to judge the accuracy of the accounts presented by the directors. It makes no difference if so called "independent" directors appoint the auditor because the accounts represent the views of all the directors. No court of law would ever allow a judge to be appointed and paid by those she was judging, yet, this practice is described as "best" governance in many jurisdictions and is mandated by the Sarbanes-Oxley legislation.

Political scientists have long explored how we can best deal with structural conflicts of interest. Most prominently the political philosopher Montesquieu proposed systems of checks and balances based on three pillars (executive, legislative and judicative branches) to prevent systematic power abuse by rulers. Corporate Governance structures could emulate such governance structures by including systemic checks and balances on the board level, rather than relying on individual ethicality. The John Lewis Partnership has given itself a constitution and emulates the checks and balance system of a democratic governance system. As is stated in their constitution:

"The Partnership operates on democratic principles and as much sharing of power among its members and representative bodies as is consistent with efficiency."

\footnotetext{
${ }^{15}$ Lord Acton expressed this opinion in a letter to Bishop Mandell Creighton in 1887.
}

The three governing authorities of the Partnership are the Partnership Council, the Partnership Board, and the Chairman. The Partnership Council, is the representative body of the employees (legislative), it entrusts management of the business to the Partnership Board, which delegates its management authority to the Chairman (executive). The Partnership Council makes strategic recommendations on the development of policy. It shares in making decisions about the governance of the Partnership, and may ask the Partnership Board or the Chairman anything it wishes, and they "must answer unless doing so would in their opinion damage the Partnership's interests". ${ }^{16}$ The Chairman is accountable to the Council who has the authority to dismiss him/her.

A Counsellor acts as the judicative, in that it seeks to ensure the partnership stay true to its principles and constitution. The counselor appoints several independent registrars that act as co-regulators.

In unitary boards directors are forced to accept the conflict of selecting and paying their own judges. A division of power into two or more boards would allow the conflicts of interest to be avoided and/or credibly managed. Various ways of introducing checks and balances are found in European countries. In many jurisdictions, at least one supervisory board is required, while in others, two may be specified. When two supervisory boards are required, one is responsible for appointing the executive board, while the other becomes responsible for appointing the auditor. After Enron, many policy makers even suggested auditors be appointed by the government in the same manner as tax auditors are. Another alternative with less government interference is self-regulation via shareholder controlled oversight boards that appoint auditors.

\section{Conclusion}

We are not arguing that the financial crisis could have been avoided if all financial and non-financial companies had adopted network governance models. However, we have reasons to believe that operational risks could have been exposed and therefore mitigated much earlier. Network governance is based on active involvement of organizational stakeholders and the engagement of multiple boards with varying functional or geographical foci. Network governance uses

\footnotetext{
${ }^{16}$ The Constitution of the John Lewis Partnership, September 2009, www.johnlewis.com
} 
the underutilized resources of stakeholder loyalty and commitment to the business, stakeholder access to competitive intelligence, product and/or service quality knowledge and innovational opportunities, as well as firm-specific and industry knowledge. The introduction of a network of boards reduces the problem of information overload, introduces checks and balances on corrupt practices, and can be used to create a requisite variety of communication and control channels to enhance performance. That way, systemic communication and control deficiencies of a unitary board can be overcome, and board members can specialize on specific aspects of the governance process.

Network governance at first sight is a counterintuitive concept. By engaging stakeholders actively and making them de facto co-controllers, we increase complexity. However, we increase complexity on the structural level only to decrease information overload at the individual level. By introducing a network of controllers, we decompose data processing and decision making labor into manageable components to provide a superior basis for decision making. Superior information can be gained through stakeholder involvement, which can then be processed more effectively by having specialized board members serve on different boards.

Early in the $1990 \mathrm{~s}$, Michael Porter argued that feedback from customers, suppliers and other stakeholders makes Japanese and German firms more competitive than US firms. ${ }^{17}$ Instead of adopting either the Japanese or German governance architecture, US and UK firms could obtain superior competitive advantages by designing a more effective and efficient form of network governance. This could be achieved through amendments to their constitutions and/or by-laws to establish various forms of Stakeholder Councils. Stakeholder elected advisory boards would provide directors and CEO's with information independent of management, which would show the other side of the management reporting story. In this way, the advisory stakeholder boards would legitimize the core duties of directors to monitor management in a credible manner, independent of management. More importantly, Stakeholder Councils provide the means to introduce a requisite variety of communication channels and co-regulators to cross check the integrity of reports and improve performance and social responsibility.

\footnotetext{
${ }^{17}$ Michael Porter in his 1992 report to The Council on Competi-
}

\section{References}

[1] BusinessWeek, $\$ 10.2$ trillion: Estimated cumulative stock losses for American households since the end of 2007 with the Dow Jones Wilshire 5000 Composite Index down by nearly 50\%, The McGraw-Hill Companies March 9 (2009), 13

[2] M. Davies and W. Siew, 45 percent of world's wealth destroyed: Blackstone CEO, Reuters, 2009.

[3] C. Fox, Accountants Point Fingers at Failed Corporate Governance as Cause of Financial Crisis, Published: October 27, 2008.

[4] N. Weiner, Cybernetics, John Wiley \& Sons, NY, 1948.

[5] D.E. Purpel, The inadequacy of moral education, Review of Education, Pedagogy, and Cultural Studies, 19(2) (1997), 257-267, 1556-3022.

[6] W.R. Ashby, An Introduction to Cybernetics, Chapman \& Hall, London, 1956, p. 206.

[7] W.R. Ashby, An Introduction to Cybernetics, Chapman \& Hall, London, 1956, p. 265.

[8] As explained by Williamson, O.E.: Markets and hierarchies, analysis and antitrust implications: A study in the economics of internal organization, Free Press, New York, 1975, pp. $132-154$.

[9] S. Turnbull, The Science of Governance, http://ssrn.com/ abstract $=316939,2001$.

[10] C. Jones, W.S. Hesterly and S.P. Borgatti, A general theory of network governance: Exchange conditions and social mechanisms, Academy of Management Review 22(4) (1997), 911-945.

[11] R. Monks and A. Sykes, Capitalism without owners will fail: A policymaker's guide to reform, Centre for the Study of Financial Innovation, New York, 2002, p. 9. Available from http:// cegopp.cema.edu.ar/download/CapitalismOwnersFail.pdf,

[12] Bebchuk, A. Lucian and Hamdani, Assaf, The Elusive Quest for Global Governance Standards. University of Pennsylvania Law Review, Forthcoming; Harvard Law and Economics Discussion Paper No. 633. 2009. Available at SSRN: http:// ssrn.com/abstract $=1374331$

[13] R.J. Thomas, M. Schrage, J.B. Bellin and G. Marcotte, How boards can be better - a Manifesto, Sloan Management Review 50 (2009), 2.

[14] S. See Turnbull, "The Science of Governance" http://ssrn.com/ abstract=316939, 2001.

[15] H. Thomas and C. Logan, Mondragón: An economic analysis, George Allen and Unwin, London, 1982, pp. 126-127.

[16] C. Jones, W.S. Hesterly and S.P. Borgatti, A general theory of network governance: Exchange conditions and social mechanisms, Academy of Management Review 22(4) (1997), 911-945.

[17] M. Pirson and S. Turnbull, Corporate Governance, Risk Management, and the Financial Crisis: An Information Processing View. Corporate Governance: An International Review 19 (2011), 459-470.

[18] J. Logue and J. Yates, Productivity in cooperatives and worker-owned enterprises: Ownership and participation make a difference, ILO, Geneva, 2005.

[19] S. Allen, Financial risk management: A practitioner's guide to managing market and credit risk, John Wiley and Sons, 2003. 
[20] M. Eckhart, Cooperative Governance a multi-perspective exploration on the strategic direction and control of cooperative groups, 2005.

[21] C. Carter and J.W. Lorsch, Back to the Drawing Board (Hardcover), Harvard Business School Press, 2004.
[22] S. Turnbull, "The Science of Governance" http://ssrn.com/abstract $=316939,2001$, p. 245. 